\title{
Potencialidade de onça ou a demanda da Pedra do Reino
}

Marcos Paulo Torres Pereira ${ }^{1}$

Resumo: O Romance d'A Pedra do Reino e o Príncipe do Sangue do Vaie-Volta, de Ariano Suassuna, narra as desaventuranças de Pedro Dinis Ferreira-Quaderna, pretendente ao trono do Império do Brasil. O relato do romance é um mistério, uma charada a ser descoberta e Quaderna, como "O Decifrador", torna-se responsável por compreender a paradoxal claraobscuridade deste sertão, um sertão-mundo constituído pelos sete reinos que compõem o sertão Cariri. Entretanto, Quaderna requeria forças, requeria uma potencialidade de onça para realizar seu destino de sangue e de herança, para tanto necessitava realizar o caminho do herói (CAMPBEL, 2007). Este estudo busca analisar os encontros simbólicos que the apareceram no caminho e como estes the serviram à transformação de comum em herói de sua narrativa.

Palavras-Chave: Ariano Suassuna; O caminho do herói; cavalaria sertaneja

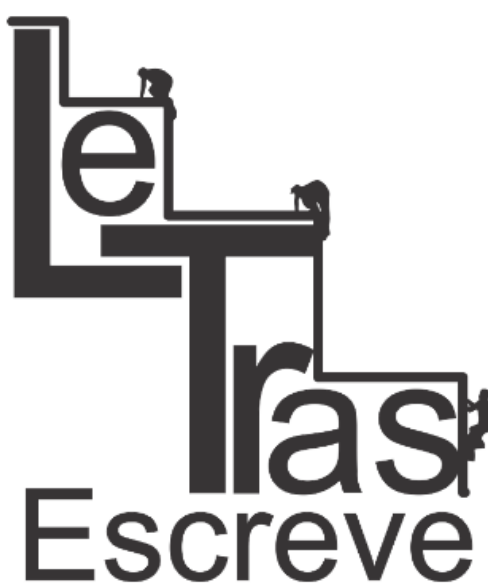

(ISSN 2238-8060)

Resumen: La novela Romance d'A Pedra do Reino e o Príncipe do Sangue do Vai-e-Volta, de Ariano Suassuna, narra las desventuras de Pedro Dinis Ferreira-Quaderna, quién pretende el trono del Imperio del Brasil. El relato de la novela se presta como un misterio, una charada a ser descubierta, y Quaderna, su personaje, será el "Decifrador"; el responsable por darnos a comprender el paradójico claro-obscuro de su sertão-mundo, un sertão constituído por los siete reinos que compone el sertão Cariri. Entretanto, Quaderna requiere de una potencia de jaguar, para realizar su destino de sangre y de herencia, para el cuál necesita realizar el camino del héroe. Este estudio busca analizar los encuentros simbólicos que aparecen en el camino del personaje enfatizando en como estos sirven para su transformación en héroe de la narración.

Palabras Clave: Ariano Suassuna; El camino del héroe; Novela de Caballería

"Esta será uma história de terror. Será uma história policial, uma narrativa de série negra e de terror. Mas não parecerá porque sou eu que conto. Sou eu que falo e por isso não parecerá. Mas no fundo é a história de um crime atroz".

(Roberto Bolano)

$\mathrm{Na}$ apresentação da $10^{\mathrm{a}}$ edição do romance $A$ história do amor de Fernando e Isaura, Ariano Suassuna afirmava que sua narrativa, tecida em 1956, era um "ensaio" de escrita, uma história

${ }^{1}$ Doutorando em Teoria e História Literária na Universidade Estadual de Campinas. Professor assistente de literaturas de língua portuguesa na Universidade Federal do Amapá. E-mail: marcospaulo@unifap.br. 


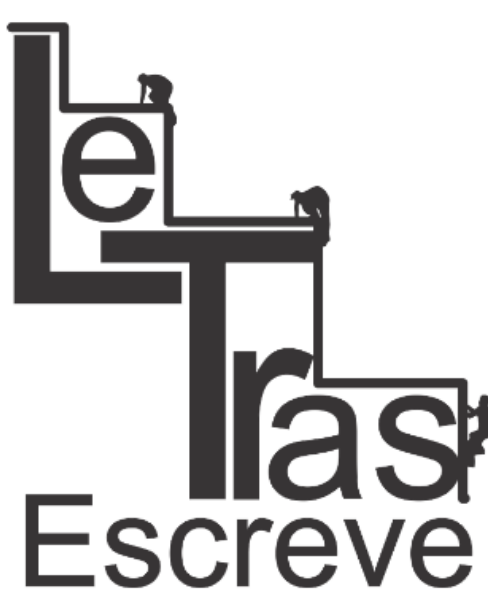

(ISSN 2238-8060)

curta que the propiciaria as condições para o desenvolvimento de uma empresa maior que seria o Romance d'A Pedra do Reino e o Príncipe do Sangue do Vai-e-Volta.

Ariano só escrevera até então poesia e teatro, entretanto, para essa dita empresa que se deu entre os anos de 1958 e 1970, o autor necessitaria da maturação de referências e de estratégias de efabulação não tão somente do "sertão mundo", mas das memórias que Ihe serviriam para matizar esse sertão em símbolos e imaginário armorial $^{2}$, na construção de um castelo literário que propiciaria ao narrador do romance, Pedro Dinis Ferreira-Quaderna, ou "Dom Pedro IV, cognominado "O Decifrador", Rei do Quinto Império e do Quinto Naipe, Profeta da Igreja Católico-Sertaneja e pretendente ao trono do Império do Brasil" (SUASSUNA, 2014, p. 33), o título de gênio da raça.

A obra, um verdadeiro labirinto narrativo e simbólico, é inacabada, a primeira parte de uma trilogia (cada uma delas seria composta de 5 livros) que abarcaria toda sua produção: teatro, poesia, romance, ensaios e artes plásticas. Sua arquitetura, cuja identidade narrativa revivifica o sertão, é, paradoxalmente, criação febril e racional ${ }^{3}$, polifônica, rompedora de linearidades, na qual

2 "A Arte Armorial Brasileira é aquela que tem como traço comum principal a ligação com o espírito mágico dos "folhetos" do Romanceiro Popular do Nordeste (Literatura de Cordel), com a Música de viola, rabeca ou pífano que acompanha seus "cantares", e com a Xilogravura que ilustra suas capas, assim como o espírito e a forma das Artes e espetáculos populares com esse mesmo Romanceiro relacionados" (DIDIER, 2000, p. 36).

${ }^{3}$ Se de um lado o epíteto da paixão evoca o espírito da narrativa, de outro a racionalidade e o planejamento dão-lhe carne. Em entrevista aos Cadernos de Literatura Brasileira do Instituto Moreira Sales, Ariano Suassuna afirmou que produzira mais de uma versão do romance e Carlos Newton Júnior em palestra intitulada "A Pedra do Reino: o sertão mítico e poético de Ariano Suassuna", no $5^{\circ}$ Ciclo de Conferências da Academia Brasileira de Letras, atribuiu esse fato ao perfeccionismo do autor, afirmando que, durante os doze anos que Suassuna levou para escrever a obra, produziu também "uns três [outros] livros, estão lá no espólio [de Ariano], de notas... de notas, mas de notas assim [sic]... livros grandes de trezentas páginas com notas sobre as personagens... desenhos.... a Clarabela como ela era?... uma mulher... ele fazia um croqui... então um negócio assim de um preciosismo... tudo isso, essas datas, essas referências todas..." (NEWTON JÚNIOR, 2015).

https://periodicos.unifap.br/index.php/letras

Macapá, v. 6, n. I, Io semestre, 2016. 


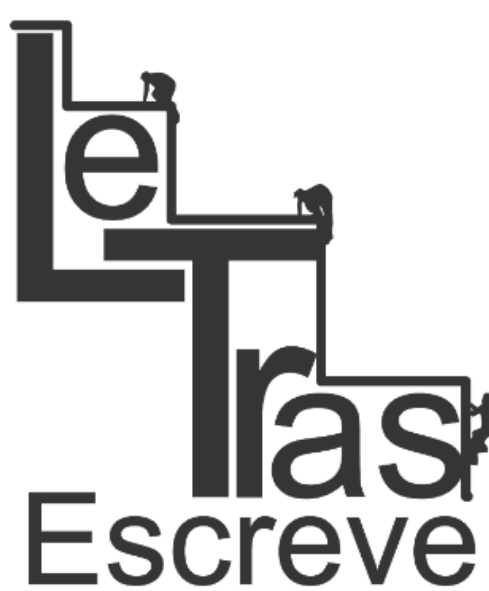

(ISSN 2238-8060) realidade e imaginário, sagrado e profano, trágico e cômico se misturam nas peripécias, artimanhas, contemplações e desaventuras de Quaderna, permitindo a seus leitores avistar além da terra árida, do homem mestiço e dos encantatórios de suas tradições, um sertão efabulado do qual emana não uma ideia de condição local, e sim uma universalidade passível de ser captada como "valor de todos".

Conseguindo se eximir de quaisquer particularidades que pudessem conduzir a narrativa para relato regionalista ou sertanejo, o romance não se ancora na verdade de descrição de uma paisagem, não batilha reproduções, tampouco firma acordo com a realidade, porém se apodera de uma "ciência" artística para a manifestação de um sertão simbólico, atingindo sua expressão mediante efabulação, símbolos e imaginário... Maturando, burilando o simbólico, alija-se da pura experiência sensorial em prol de um encantatório que possibilita ao leitor a fruição de um sertão que "não era mais somente o 'sertão' que tanta gente via, mas o Reino com o qual (...) sonhava, cheio de cavalos e Cavaleiros de frutas vermelhas de Mandacarus reluzentes como estrelas, bicadas pelas flechas aurinegras dos Concrizes e respondendo às cintilações prateadas de outras estrelas" (SUASSUNA, 2014, p. 561).

Em entrevista aos Cadernos de Literatura Brasileira do Instituto Moreira Sales (2000), Suassuna explica que a gênese d'A Pedra do Reino se relaciona diretamente com a memória de seu pai, assassinado em decorrência da situação política vivida pelo estado da Paraíba na década de 1930. Seu objetivo era escrever, já em 1950, uma biografia que se chamaria Vida do presidente Suassuna, cavaleiro sertanejo, entretanto a carga de sofrimento the fora onerosa e a escrita não se realizou. Não obtendo sucesso na primeira empreitada, tentou um poema longo que se chamaria "Cantar do potro castanho", em 1954, também não conseguindo. Em 1958 começou a tomar notas para a escrita do romance, entretanto este somente iria a público em 1971, pela editora José Olympio.

https://periodicos.unifap.br/index.php/letras Macapá, v. 6, n. I, Io semestre, 2016. 


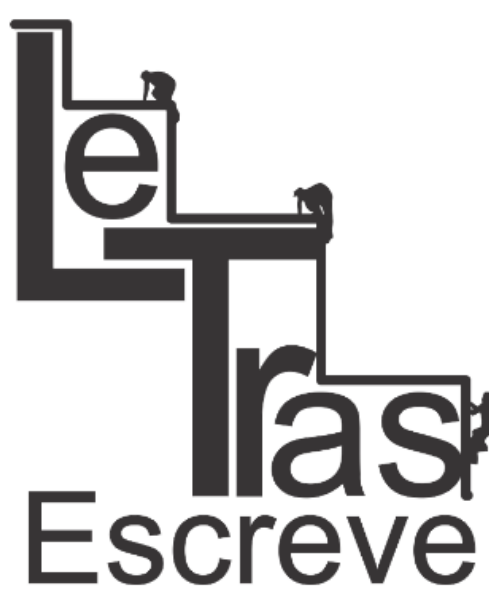

(ISSN 2238-8060)

Ainda nessa entrevista, quando inquerido se a Pedra seria uma espécie de vingança pelo assassínio de seu pai, Suassuna afirmou que ao invés disso, tratava-se de uma tentativa de recuperação, uma forma de se erguer um monumento ao pai... Do trauma da morte, uma pulsão de ficção 4 que efabularia os acontecidos que levaram à morte João Suassuna, dotando de símbolos o relato a fim de, ao filho, desanuviar-se um por quê.

A pena era de Suassuna, mas as palavras a Quaderna pertenciam. Ao ser preso em Taperoá por autoridades do Estado Novo, este relata sua epopeia, seu memorial, expressando sua vivência nos fatos que levaram seu padrinho, o fazendeiro Pedro Sebastião Garcia-Barretto, ao assassínio por degola. É o inquérito o fio motriz que trança os fatos por ele engendrados no romance, numa renda labiríntica e simbólica que investiga os acontecimentos.

Quaderna dirige-se ao povo brasileiro "à guisa de defesa e de apelo" (SUASSUNA, 2014, p. 34) ante o processo em que se vê envolvido, subvertendo em proveito próprio o objetivo primário da peça (sua acusação), no afã de tornar em documento, em registro táctil, o relato que antes lhe seria somente memória ${ }^{5}$, descortinando ao leitor o sertão castanho e mestiço mediante a tessitura de sua narrativa que se apodera de fatos reais, míticos e literários em uma renda de relatos orgânicos a um só tempo verdadeiros e ficcionais ${ }^{6}$.

Escutem, pois, nobres Senhores e belas Damas de peitos brandos, minha terrível história de amor e de culpa; de sangue e de justiça; de sensualidade e violência; de enigma,

\footnotetext{
4 "A pulsão de ficção é a necessidade imperiosa de contar para atribuir um sentido, corrigi-lo, entender, ou tentar compreender" (SPERBER, 2009, p. 577).

5 "porque assim meus depoimentos, tornados oficiais e consagrados por um documento do Governo como o inquérito, terão essa história como abertura!" (SUASSUNA, 2014, p. 357).

${ }^{6}$ No Romance da Pedra do Reino há uma polifonia de vozes que gera presença de realidades: realidade histórica (o Levante da Princesa e os movimentos messiânicos sertanejos, por exemplo); realidade sertaneja (sinais de tradição e de mentalidade cristalizados no texto literário); realidade do texto (fatos vivenciados pelas personagens na obra); e a realidade castanha (o substrato filtrado pela percepção de Quaderna da realidade do texto).
}

https://periodicos.unifap.br/index.php/letras

Macapá, v. 6, n. I, Io semestre, 2016. 


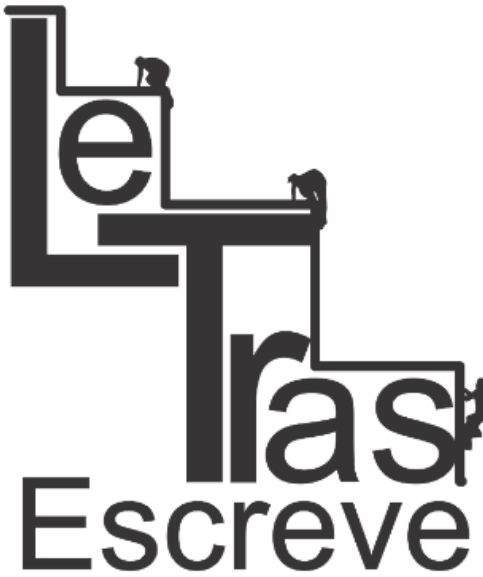

(ISSN 2238-8060)

de morte e disparate; de lutas nas estradas e combates nas Caatingas; história que foi a suma de tudo o que passei e que terminou com meus costados aqui, nesta Cadeia Velha da Vila Real da Ribeira do Taperoá, Sertão dos Cariris Velhos da Capitania e Província da Paraíba do Norte (SUASSUNA, 2014, p. 35).

A narrativa do inquérito ${ }^{7}$ se inicia no dia $1^{\circ}$ de junho de 1935 , véspera de Pentecostes, com uma cavalgada adentrando a cidade de Taperoá, no sertão do Cariri. A escolha desse fato é simbólica, por se tratar de um acontecimento "bastante bandeiroso e cavalariano para dar um tom régio" (SUASSUNA, 2014, p. 357) à obra, na evocação de uma imagética armorial na qual sinais de identidade medieval ibero-moura cristalizadas na mentalidade nordestina e sinais de espírito negro e ameríndio tornam-se sincréticos.

Mais do que funcional (por ser, segundo o narrador, o que daria início aos acontecimentos que o levariam à prisão), essa escolha revela a preocupação em burilar o real do texto com o formão do imaginário e da literatura ${ }^{8}$, efabulando o relato.

A cavalgada do Rapaz-do-Cavalo-Branco, como ficou conhecido o acontecimento nos autos, trazia à frente três homens, cavaleiros do sertão, sob os quais se deposita um fabulário

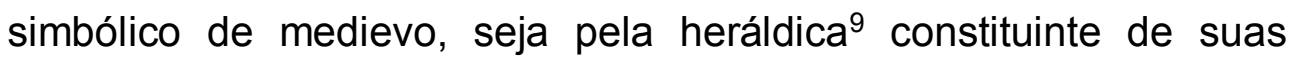

\footnotetext{
${ }^{7}$ E não da obra, que se inicia em 9 de outubro de 1938 com Quaderna preso na cadeia de Taperoá, pois há um ir e voltar de tempos e subversões de ordem, por vezes comandados por rememorações, outras por força do inquérito, que quebram a lineariedade do relato.

${ }^{8}$ No mesmo enxerto que narra a cavalgada se faz referência às obras $O$ Guarani e O Sertanejo, de José de Alencar, que também se iniciam por cavalgadas. Quaderna, como pretendente ao título de Gênio da Raça, não poderia ficar atrás de um de seus mestres literários e assim adere ao modelo engendrado por Alencar.

${ }^{9}$ A heráldica é a ciência que estuda os brasões, insígnias ou distintivos de famílias nobres. Ciência que interpreta também ornatos e figuras dispostos no campo de um escudo ou fora dele, representando as armas de uma nação, um soberano, família, corporação ou cidade. Funcionalmente, servem os brasões não só como forma de distinção entre classes, entre diferentes, mas como modo de identificação e de pertencimento entre iguais. Simbolicamente, por serem conferidos, em regra, por merecimento, representam honra e glória (PEREIRA, 2014, p.188).
}

https://periodicos.unifap.br/index.php/letras

Macapá, v. 6, n. I, Io semestre, 2016. 


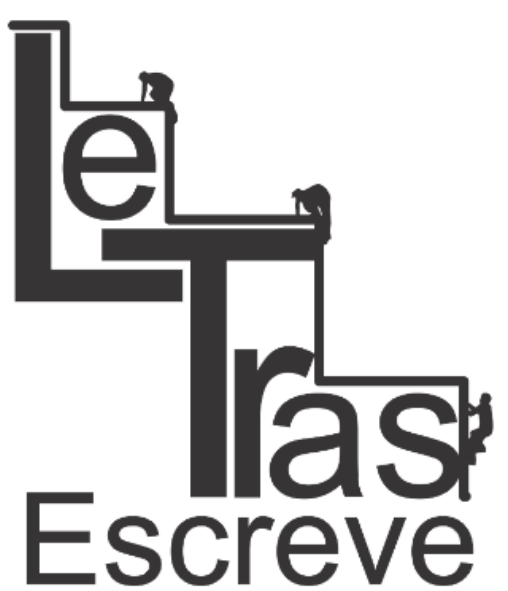

(ISSN 2238-8060)

bandeiras, seja pelo caráter entre o militar e a anunciação, como batedores de uma procissão: o primeiro, a cavalo, conduzia uma bandeira com três onças estampadas, estandarte que reunia aqueles que os seguiam; o segundo, um lanceiro, com uma cruz que "vinha cheia de gaviões e carcarás, amarrados pelos pés a argolinhas cravadas na madeira" (SUASSUNA, 2014, p. 39); e o terceiro, um monge guerreiro, com a bandeira do Espírito Santo do Sertão.

Se a onça, nos moldes de insígnias, torna-se ornato de manifestação simbólica, sua exposição com Carcarás e Gaviões servem de evocação à morte, que no sertão nordestino é a Caetana e que, no relato engendrado no Romance d'A Pedra do Reino, é a Moça Caetana, ou Onça Caetana, de acordo com a forma como ela se manifeste.

Entretanto, mesmo o relato do inquérito se fazendo presente desde as primeiras páginas da obra, é somente ao fim do Folheto $\mathrm{XLIX}^{10}$ ("A Cadeia”), que Quaderna se apresenta ao Corregor que iria lhe inquirir:

sou ainda redator da Gazeta de Taperoá, jornal conservador e noticioso no qual me encarrego da página literária, enigmática, charadística e zodiacal. Posso dizer, assim, que além de Poeta-escrivão e bibliotecário, sou jornalista, Astrólogo, literato oficial de banca aberta, consultor sentimental e diascevasta do Brasil (SUASSUNA, 2014, p. 337).

Graças à legitimidade textual interna (premissa cujos fatos do texto se comprovam mediante o próprio texto), "a identidade de personagens de ficção é inquestionável” (ECO, 2013, p. 83),

\footnotetext{
${ }^{10}$ A obra se divide em cinco livros, estes subdivididos em 85 "folhetos". Os livros são: "I - A Pedra do Reino"; "II - Os emparedados"; "III - Os três irmãos sertanejos"; "IV - Os doidos"; e "V - A demanda do sangral". Ariano pretendia desenvolver uma trilogia, sendo $A$ Pedra do Reino o primeiro deles, com cada romance se dividindo em cinco livros. Dessa empreitada, veio a público somente o primeiro romance e parte do segundo (Historia d'o rei degolado nas caatingas do sertão e Infâncias de Quaderna - este segundo somente em fascículos por um jornal de Recife, nunca tendo sido juntado em livro).
}

https://periodicos.unifap.br/index.php/letras

Macapá, v. 6, n. I, Io semestre, 2016. 


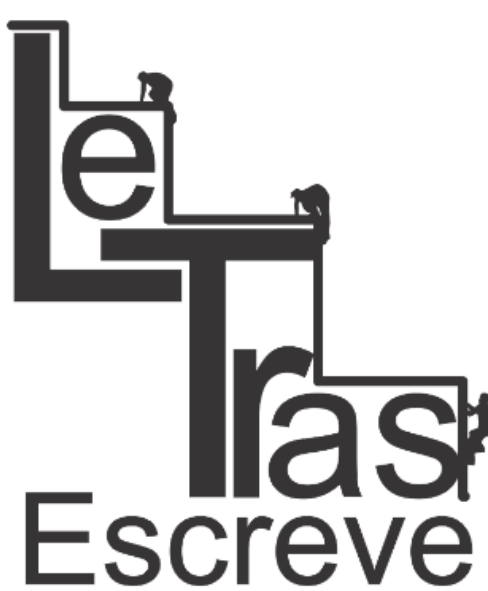

(ISSN 2238-8060)

porquanto este enxerto se torna importante à compreensão de afluências identitárias que corporificam as veias da narrativa, à proporção que se apresenta um devir discurso constituído por mundos diferentes e plurais, virtualmente infinitos, que em certa medida profanam o acadêmico pelo popular, o real pelo imaginário, o pragmático pelo subjetivo em fluxo e refluxo contínuo.

Todo o relato do Romance d'A Pedra do Reino é um mistério, uma charada a ser descoberta na amálgama de fontes e influxos efabulados como manifestação de pistas do discurso charadístico. Dom Pedro Dinis Ferreira-Quaderna, como "O Decifrador", torna-se responsável por compreender a paradoxal clara-obscuridade deste sertão, um sertão-mundo constituído pelos sete reinos que compõem o sertão Cariri11, envolto em símbolos de sagração armorial a fim de cumprir a previsão feita pela Moça Caetana: "Só Ihe pertence o que por você for decifrado" (SUASSUNA, 2014, p. 306).

Quaderna atribuía como causas imediatas à sua prisão a degola do padrinho (centro enigmático de crime e sangue de sua história) e a chegada do Rapaz-do-Cavalo-Branco em Taperoá (que se acreditava ser seu primo "Sinésio, O Alumioso, esperança e bandeira do Reino Sertanejo" - SUASSUNA, 2014, p.62), porém apontava outras, relativas à Cantiga de La Condessa e aos sangrentos ocorridos entre 1835 a 1838, na Serra do Reino, quando sua "família ocupou o trono do Brasil, no Sertão da Pedra do Reino, entre o Pajeú de Pernambuco e o Piancó da Paraíba" (SUASSUNA, 2014, p.67).

\footnotetext{
11 "O mundo suassuniano tem uma particularidade geográfica: sua capital é Taperoá, uma pequena cidade dos Cariris Velhos, no sertão da Paraíba (...). A relação de Ariano Suassuna com o sertão, com a terra, passa obrigatoriamente por Taperoá, essa parte do mundo que the foi "dada". Essa relação é dupla: o homem pertence ao sertão tanto quanto o sertão Ihe pertence e, reencontrando o caráter movediço já evocado, o sertão cresce às dimensões de mundo (...). Que sertão é esse? Para Suassuna, não é somente o espaço vago e movediço do qual já falamos: o sertão tornou-se um império incluindo sete reinos, definidos com precisão pelo narrador" (SANTOS, 2009, p. 69-70).
}

https://periodicos.unifap.br/index.php/letras

Macapá, v. 6, n. I, Io semestre, 2016. 
Quaderna confessa que a história de sua ascendência the incendiava o sangue desde a puberdade, dado o sacrifício de sangue que seu avô, El-Rei Dom João Ferreira-Quaderna, O Execrável, exigira a seus seguidores a fim de lavar as torres da Pedra do Reino de sangue e assim libertar Dom Sebastião de sua prisão para que se estabelecesse o reino glorioso na terra.

O pai de Quaderna, Dom Pedro Justino, e sua tia, Dona Filipa, tinham medo que o sangue das 53 pessoas imoladas recaísse sobre a família, por isso mantiveram segredo do "estigma vergonhoso e de mancha indelével" de seu sangue. O narrador só descobriu aos doze anos o passado de sua família, quando o Cantador João Melchíades Ferreira, padrinho e parente do narrador, contou-lhe os acontecimentos astrosos e fatídicos ocorridos na Pedra do Reino, que Ihe davam de herança o espírito régio, profético e cavaleiresco:

a história das degolas, o Vinho encantado, as noivas que meu bisavô dispensava na noite de núpcias e antes dos maridos etc. Vi que meu bisavô fora Rei, mas fora, também, Profeta de um Catolicismo que Pereira da Costa chamava de "particular", sertanejo. Vi também que aquele era o Catolicismo que me convinha, uma religião que, a um só tempo, me permitia ser Rei e Profeta, e ter tantas mulheres quantas pudesse; comer as carnes que quisesse em qualquer dia da semana e beber tanto vinho quanto me desse na veneta, incluindo-se entre estes o Vinho sagrado da Pedra do Reino, que nos mostrava o Tesouro antes mesmo que ele fosse desencantado e descoberto. Era, em suma, uma religião que me salvava a alma e, ao mesmo tempo, permitia que eu mantivesse meu bom comer, meu bom beber e meu bom fuder, coisas com as quais afastava a tentação da visagem da Onça e da Cinza (PR, p. 543).

Quaderna explica que a transformação do medo e da repulsa em orgulho e admiração foi gradual, à medida que seus mestres e suas leituras (de folhetos de cordel, de trabalhos acadêmicos de eruditos do Séc. XIX - sejam eles reais ou fictícios) expressaram-lhe não somente a essência cavalheiresca do sertão, mas que a marca de sangue é comum às famílias governantes.

https://periodicos.unifap.br/index.php/letras

Macapá, v. 6, n. I, Io semestre, 2016. 
Suassuna apodera-se do real, de um movimento sebastianista, e lhe tinge com a cor castanha, ligando-o a história da família de Dinis, à proporção que ficcionaliza o beato líder da comunidade, agora então antepassado de Dinis. Uma genealogia marcada pelo sangue e pelo assassínio, ressignificando, numa leitura mais ampla, o epíteto de morte Caetana à família dos Ferreira-Quaderna:

Doutor Samuel Wanderners me disse um dia que eu, além do sangue cigano-árabe e godo-flamengo, tenho ainda umas gotas de sangue judaico, herdadas de minha mãe, Maria Suplícia Garcia-Barretto. Depois daí, entendi: de qualquer modo eu estaria incluído entre os criminosos mais ilustres do mundo - aqueles que, por terem tido a coragem de matar Deus, tinham propiciado a todos os homens a possibilidade ascender e se igualar ao Divino. Quanto ao Professor Clemente, provou-me ele um dia, (...) que todas as famílias reais do mundo são compostas de criminosos, ladrões de cavalo e assassinos, de modo que a minha não era, absolutamente, uma exceção (SUASSUNA, 2014, p. 65).

Melchíades fora-lhe 0 primeiro guia nos pródromos à demanda que lhe geraria a potência necessária para assumir o reino, entretanto logo outros dois Ihe apareceram, Professor Clemente Hará de Ravasco Anvérsio e Doutor Samuel Wandernes. O primeiro fora convidado pelo tio de Quaderna, Dom Pedro Sebastião Garcia-Barretto, a morar na Fazenda Onça Malhada para ser preceptor de Dinis e de seus primos, Arésio, Silvestre (o bastardo), e Sinésio (o Alumiado). O segundo, Dr. Samuel, viera à fazenda com o intuito de realizar pesquisas sobre a genealogia dos Garcia-Barrettos, a quem dedicaria parte do livro que escrevia sobre a fidalguia sertaneja e a dos engenhos de Pernambuco... O tempo fora passando, porém Samuel permanecendo.

Para Samuel, a família dos Garcia-Barrettos descendia de Dom Sebastião, que sobrevivera a batalha de Alcacer-Quibir e se radicara no Brasil em 1578, com o nome Dom Sebastião Barretto, a fim de retomar suas forças, sua "honra de soldado e suas perdidas esporas de Cavaleiro". No entanto, para o pai de Quaderna, de 
acordo com os estudos genealógicos que realizara, a família descendia do Rei Dom Dinis, o Lavrador (esse era o motivo das desavenças de Samuel com o pai de Quaderna).

O narrador passa então a construir um discurso didáticoacadêmico matizado por um espírito nobiliárquico que justificaria ao leitor sua ascendência régia, como legítimo herdeiro ao trono do Brasil, à implantação do Quinto Império:

Para narrar essa história, valer-me-ei o mais que possa das palavras de geniais escritores brasileiros, como o Comendador Francisco Benício das Chagas, o Doutor Pereira da Costa e o Doutor Antônio Áttico de Souza Leite, todos eles Acadêmicos ou consagrados e, portanto, indiscutíveis: assim, ninguém poderá dizer que estou mentindo por mania de grandeza e querendo sentar de novo um Ferreira-Quaderna, eu, no trono do Brasil, pretendido também - mas sem fundamento! pelos impostores da Casa de Bragança. Faço isso também porque assim, nas palavras dos outros, fica mais provado que a história da minha família é uma verdadeira Epopeia, escrita segundo a receita do Retórico e gramático de Dom Pedro II, o Doutor Amorim Carvalho: uma história épica, com Cavaleiros armados e montados a cavalo, com degolações e combates sangrentos, cercos ilustres, quedas de tronos, coroas e outras monarquias - o que sempre me entusiasmou, por motivos políticos e literários que logo esclarecerei (SUASSUNA, 2014, p.63).

Quaderna requeria forças, requeria uma potencialidade de onça para realizar seu destino de sangue e de herança, para tanto necessitava realizar o caminho do herói ${ }^{12}$ - a demanda ou a jornada comuns aos relatos míticos que arrebataria um indivíduo de uma existência comum para a condição de herói (CAMPBELL, 2007) -, o que se deu nos Folhetos XVII, XVIII e XX, respectivamente a primeira, a segunda e "A Terceira Caçada Aventurosa".

${ }^{12}$ Segundo Campbell, o "caminho do herói" segue uma estrutura cíclica de forma a emular ritos de passagem, no qual o indivíduo, mediante uma provação, é transformado de seu estágio inicial em algo maior, melhorado. Mesmo voltando ao ponto de origem após a jornada, aquele que voltou não mais é o que iniciou a jornada, pois os empecilhos lhe moldaram. É uma aventura mitológica que se inicia com a partida/separação; passando pelo momento transformador das provações, a iniciação; e o retorno, que se inicia com o empossar da essência heroica e se encerra com sua volta para seu ponto de origem.

https://periodicos.unifap.br/index.php/letras

Macapá, v. 6, n. I, Io semestre, 2016. 
Leitor voraz e afilhado literário do "Oncismo" do Professor Clemente e do movimento literário do Doutor Samuel Wandernes, o "Tapirismo Ibérico-Armorial do Nordeste", o narrador assume durante esses folhetos uma figuração régia mediante a sagração do Quinto Império, que estava diretamente ligada à Onça-Malhada (fazenda da família de Quaderna, que constitui na obra um dos sete reinos) e a seus mistérios, ressaltando a um só tempo a magia, o enigma, o transcendental e o poder que figurativamente exerceria através da alegoria, nos liames de romances de cavalaria.

Coube à literatura o papel de enaltecer a imagem do herói medieval, ao criar a ilusão de que as virtudes viris dos cavaleiros andantes eram, por definição, a realização de um ideal de justiça, tanto na origem desse gênero no medievo, quanto no seu ressurgimento no início do século XIX, mediante o resgate temático do passado heroico dos países europeus no Romantismo, a fim de justificar o nacionalismo nessas nações através da figura do herói nacional representado pelo cavaleiro andante. Johan Huizinga (2013, p. 99) afirma:

Como ideal de vida bela, a concepção cavaleiresca tem aspectos peculiares. É um ideal (...) feito de fantasias coloridas e sentimentos elevados, que também almeja ser um ideal estético: o pensamento medieval só pode conferir nobreza a um ideal de vida se o puder vincular à piedade e à virtude. Nessa sua função ética, o ideal cavaleiresco fica sempre a dever, estorvado por sua origem pecaminosa. Pois o cerne do ideal é sempre o orgulho elevado à condição de beleza.

Entretanto, o cavaleiro Dinis não era o europeu de "sentimentos elevados", tampouco aquele afiliado à piedade e à virtude, mas o cavaleiro do sertão, o homem livre, transgressor das amarras que se lhe impõem em prol de seu direito de sangue:

Pela leitura deles, eu via que os Heróis parece que só faziam três coisas, na vida: porque, quando não estavam na mesa, comendo e bebendo vinho, estavam, ou na estrada, brigando, montados a cavalo, armados de espadas e com bandeiras desfraldadas ao vento, ou então na cama, montados em

https://periodicos.unifap.br/index.php/letras

Macapá, v. 6, n. I, Io semestre, 2016. 
alguma Dama, trepando senhoras e donzelas desassistidas. Vida era aquela, a vida dos Cangaceiros medievais como Roberto do Diabo, ou dos Guerreiros sertanejos como Jesuíno Brilhante, homens vestidos de Armaduras de couro, armados de espadas compradas em Damasco ou no Pajeú, bebendo vinho de Jurema e Manacá, vencendo mil batalhas e sempre aptos a possuir mil mulheres. Estas, mesmo quando não gostavam disso no começo, terminavam gostando no fim: primeiro, por causa da fama deles; depois porque, como me dizia uma recém-casada sertaneja em meu "Consultório Sentimental e Astrológico", "esse negócio de fuder no começo é um pouco incomodatício, mas depois até entrete".

Sobre a concepção de herói sertanejo, Idelette Muzart vaticina:

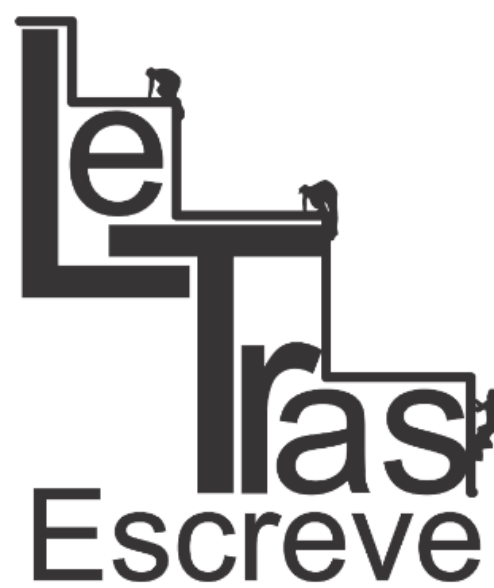

(ISSN 2238-8060)

Toda sociedade precisa de heróis para projetar suas aspirações e compensar suas frustações. $\mathrm{Na}$ estrutura piramidal que "segura" todos os habitantes do sertão, o herói é antes de mais nada um homem livre, que prova cotidianamente sua coragem, como por exemplo o vaqueiro, o homem a cavalo; em segundo lugar, é um homem só, que se declara em luta contra a sociedade, rejeita-a e ousa transgredir seus tabus, pelo crime e pela fé. Cangaceiro ou beato, não pertence ao mesmo mundo, rompeu com ele para assumir sua própria identidade (SANTOS, 2009, p. 88).

A conquista das torres ${ }^{13}$ da Pedra do Reino era necessária para que se desse a sagração do Quinto Império sob o signo da onça, pois no discurso fidalgo de Quaderna esta era sua herança. O narrador precisava tomar posse daquilo que decifraria, precisava tornar-se herói de sua história assumindo uma essência que lhe dotasse de poder, por isso o relato se erige mediante um único ponto de vista, o da onça, abarcando nesse repositório simbólico todas as manifestações que Ihes são ulteriores, da heráldica bandeirosa à Morte Caetana (que é moça e também onça), passando pelas acepções da Onça do Mundo no macro universo sertanejo e da Onça Malhada (lugar das memórias de infância de Quaderna).

13 Tratam-se de uma formação natural de duas rochas situada no sertão do Pajeú, fronteira da Paraíba com Pernambuco, que se assemelham a torres de um castelo no imaginário popular.

https://periodicos.unifap.br/index.php/letras

Macapá, v. 6, n. I, Io semestre, 2016. 


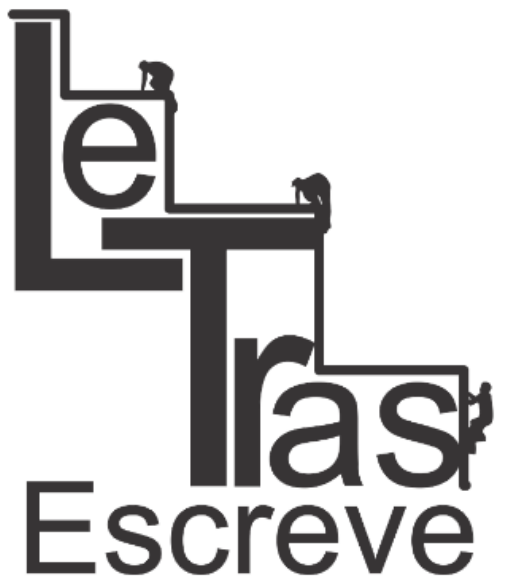

(ISSN 2238-8060)

O lugar, por definição, evoca uma manifestação identitária (SANTOS, 2006) num mosaico de sinais históricos, étnicos, sociais, geográficos, culturais, religiosos etc. No romance, a Pedra do Reino se localizava nas terras de Pereira da Costa, aliado do finado padrinho de Quaderna durante o Levante da Princesa ${ }^{14}$, o que Ihe forçou a um exílio da base angular de seu reino, destruindo-lhe a identificação com a figuração régia que buscava erguer, num desenraizamento que corrói laços simbólicos: "não ter raízes significa não ter no mundo um lugar reconhecido e garantido pelos outros; ser supérfluo significa não pertencer ao mundo de forma alguma" (ARENDT, 1990, p. 528).

Para Campbell (2007) a jornada do herói parte de um mundo que the é conhecido, comum, ordinário, para um mundo que não the é conhecido, um mundo especial. Taperoá era a terra de morada de Quaderna, mas seria somente na Pedra do Reino que encontraria suas raízes, sua identidade e sua potência de onça pelas provações que enfrentaria. Seguindo a estrutura estabelecida por Campbell, a partida do herói se inicia com o "chamado da aventura": a necessidade imperiosa de visitar as rochas do Reino, porém a "recusa do chamado" Ihe aparecia na ciência da quase impossibilidade de realização de seu anseio:

\begin{abstract}
Era um sonho grandioso, um sonho à altura da estirpe dos Quaderna. No fundo, porém, lá bem longe e bem dentro do meu sangue, reprimido pela covardia, vigiava ainda o desejo de reconquistar o Castelo real, o da Pedra do Reino. Não o de erguer um Castelo poético, como o dos Cantadores; mas o de ir ao Pajeú e retomar, a patas de cavalo, ponta de punhal e tiros de rifle, o Castelo de pedra que era meu e que os Pereiras tinham conquistado. Só assim eu poderia ser, também, Rei do Sertão, como Jesuíno Brilhante e meu bisavô. Só assim eu seria, de fato, o Cavaleiro que, encarnando o Brasil, seria estimado e honrado pelos amigos, temido pelos inimigos e
\end{abstract}

${ }^{14}$ O Levante da Princesa se deu no início da década de 1930, quando o coronel José Pereira, da cidade de Princesa Isabel, rebelou-se contra o presidente da Paraíba, João Pessoa, que queria desarmar os coronéis. Nessa rebelião, proclamou a independência da Vila, outorgando-lhe inclusive hino e bandeira. $O$ fato acabou desencadeando outros que acarretaram na morte do pai de Ariano Suassuna.

https://periodicos.unifap.br/index.php/letras

Macapá, v. 6, n. I, Io semestre, 2016. 


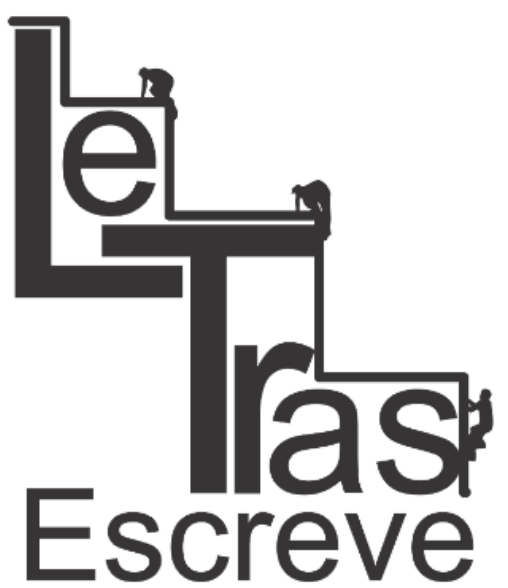

(ISSN 2238-8060) amado pelas mulheres, belas Princesas parecidas com Rosa, a da "Onça Malhada", e com Marina, a do folheto. Gozaria de todas a meu prazer, tendo as primícias das donzelas e podendo até degolá-las, caso isso me desse na veneta, como tinha dado na do meu bisavô, "O Execrável" (SUASSUNA, 2014, p. 116).

Dinis decide fazer viagem às terras dos Pereira. Emprega de uma desculpa qualquer a seus anfitriões, que seu desejo deveria permanecer em segredo, e convida para acompanhá-lo um homem de letras, o fidalgo Euclydes Villar ${ }^{15}$, e outro dos Quadernas, seu irmão Malaquias. As escolhas são o "auxílio sobrenatural" que evocam "uma atmosfera de irresistível fascínio em torno da figura que aparece subitamente como guia, marcando um novo período, um novo estágio, da biografia" (CAMPBELL, 2007, p. 64), pela possibilidade que Euclydes teria em "florear", em tornar literários os feitos de Quaderna, e pela força do irmão ("o poder benigno e protetor do destino" - CAMPBELL, 2007, p. 76) que, se preciso fosse, poderia auxiliá-lo nas armas:

A presença de Malaquias era-me indispensável porque ele, ao contrário do que acontece comigo é corajoso, bom Cavaleiro, bom atirador e bom caçador. Os Quadernas são altos, mas Malaquias é o mais alto, robusto e bem proporcionado de todos. Creio que, em todo o Cariri, só havia dois homens capazes de derrotar Malaquias numa luta corpo a corpo. O primeiro, era Marino Quelê Pimenta, pela descomunal força física. O outro, era meu primo Arésio Garcia-Barretto, filho mais velho de meu Padrinho: não porque fosse muito mais forte, mas porque, na luta, Malaquias combateria pela alegria do combate, enquanto Arésio, moreno e cerrado, depois de receber os primeiros golpes, não poderia impedir que irrompesse de dentro dele aquela violência obscura e cega que morava nos recessos de seu sangue e que foi a causa de tantos infortúnios para nós e para ele mesmo (SUASSUNA, 2014, p. 119).

Durante a viagem é que se deram as ditas "caçadas aventurosas" que marcam a transformação de Dinis em Dom Pedro

15 É notória a admiração de Ariano Suassuna por Euclides da Cunha, porém não há indícios suficientes no romance para concluir se o nome desse fidalgo se deu em homenagem ou evocação ao escritor.

https://periodicos.unifap.br/index.php/letras

Macapá, v. 6, n. I, Io semestre, 2016. 


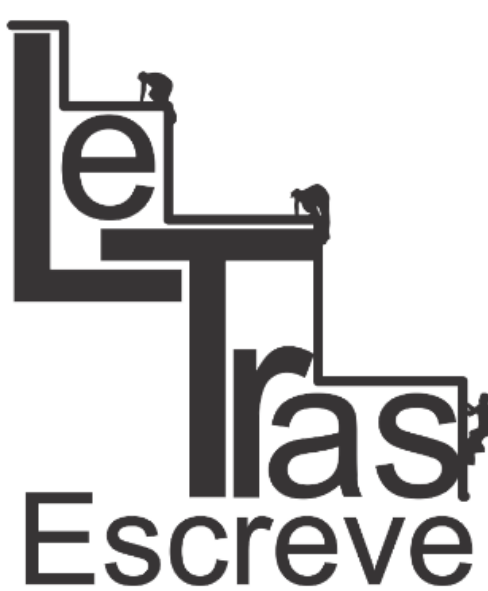

(ISSN 2238-8060)
Dinis Ferreira-Quaderna, ou "O Decifrador", Rei do Quinto Império. Três foram os fatores que propiciaram essa transformação: 1) embate dos Quadernas com os Pereiras pela honra de maiores caçadores (não pode haver vencedores se não houver derrotados, não pode haver herói se não lhe sobrevier uma nêmeses); 2) a representação das presas abatidas, numa gradação de quantidade e qualidade; e 3) a Fortuna que sorri para Quaderna e the vem em auxílio em passagens cruciais de seu caminho heroico.

A primeira caçada (nos moldes estabelecidos por Campbell, "a passagem pelo primeiro limiar") é o início da encarnação de onça por Quaderna, que começa a abandonar a potencialidade pela realização, através de seus feitos como fera-de-presa, como caçador. É a entrada na aventura, o início dos testes que deverá enfrentar, "além desses limites, estão as trevas, o desconhecido e o perigo" (CAMPBELL, 2007, p. 82). A primeira presa que the apareceu foi uma rolinha "Caldo-de-Feijão", que de chofre quis abater, entretanto Malaquias (como guia) Ihe diz para ignorá-la por ser caça pequena e por depender de um tiro que poderia assustar caças maiores que se anunciavam, marrecos.

Dinis estava agora no meio do mato, seu "ventre de baleia", que para Campbell é o mote da autoaniquilação característico à passagem pelo limiar, por isso o herói sofre censuras por seus talentos de caçador, por pensar em dar o bote sem quaisquer preparações e sem aferir quaisquer critérios de valor às presas. Mas os dotes de poeta não o deixaram desprotegido, fazendo com que se defenda através das "tiradas" e gracejos: "Minha sede de caçador é tanta que, vendo a caça menor, perto, nem me lembrei que podia espantar a maior! Mas isso é de quem é caçador, mesmo, e, como diz o ditado, "é melhor uma Rola na mão do que duas no cu!" (SUASSUNA, 2014, p. 124).

Em seguida, foi a vez de aparecerem Marrecas, que Malaquias, de pronto, duas abateu, trazendo honra à família dos Quaderna e os primeiros sinais de ciúme aos Pereira, que se

https://periodicos.unifap.br/index.php/letras Macapá, v. 6, n. I, Io semestre, 2016. 


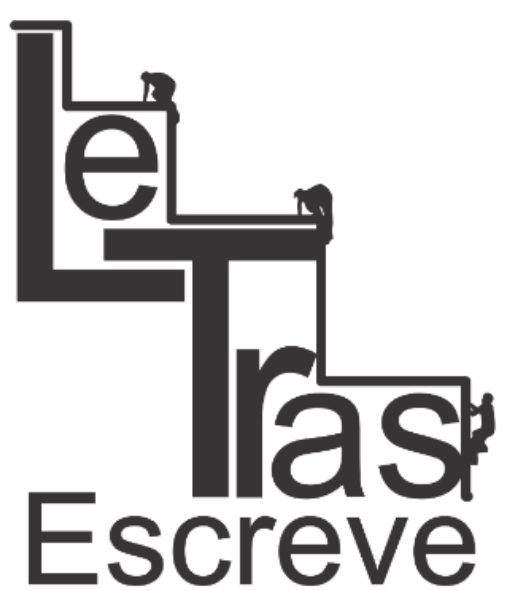

(ISSN 2238-8060) mostravam reticentes, atribuindo o sucesso de Malaquias não a sua pontaria, e sim a sua espingarda. O "combate" se iniciava: Quaderna imediatamente retrucou, dizendo que tanto era raçuda a espingarda quanto o caçador.

Depois aparece uma rolinha cascavel, que Dinis erra. Logo após, um casal de rolinhas e novos erros dos tiros do irmão menos afortunado (até o momento) dos Quaderna. A primeira caça abatida por Dinis fora um sabiá, que voara do chão aos galhos de uma árvore que formavam uma forquilha. Auxiliado pela marcação natural de mira, Quaderna abate sua primeira presa. Contudo, o moleque que acompanhava os caçadores como guia e como carregador das aves abatidas não perdeu a oportunidade de destilar chacota contra Dinis. Novamente, as palavras surgiram onde faltaram as habilidades de caçador:

(...) E eu começava, já, a me sentir orgulhoso, quando ouvi o rapagote dizer, atrás de mim, a frase tradicional e escarninha:

- Até que enfim esse homem, aí, tirou o dedo do fioto!

- Tirei do meu e soquei no seu, desgraçado! - retruquei imediatamente. - Tirei o dedo do meu rabo e soquei no seu! Agora, trate você de tirar ele daí!

Novamente os Pereiras caíram na gargalhada. O rapaz encabulou um pouco e gaguejou: - Bem, eu disse assim porque é da regra, mas que foi um bom tiro, foi! Acertou em cheio, e o bicho já caiu fedendo! (SUASSUNA, 2014, p. 127)

Quaderna se afasta de seus companheiros para, além de buscar outras presas, poder atirar sem a pressão de julgamentos. Contudo, isso não muda seus augúrios: apareceram-lhe duas rolinhas "fogo-apagou" e ele erra os dois tiros. Pela primeira vez caracteres felinos Ihe sobressaem, quando começa a armar tocaia para uma juriti:

Deixei a vereda, entrei pelo mato, parei a certa altura, com as pernas enganchadas numa rama. Aproveitei a pausa para verificar se a Juriti voara: mas ela continuava a cantar, sossegada. Desenganchei-me bem devagarinho, para não fazer barulho, e comecei a tomar chegada, macio e traiçoeiro como um gato. De repente, ouvi a Juriti cantar de novo, a uns 
dez passos de mim. Olhando na direção do canto, avistei-a, muito despreocupada de si, pousada no galho de uma Jurema meio florada. Com o coração aos saltos, levei a "Vinte e Oito" à cara e comecei a mirá-la. No momento exato em que ia atirar, porém, soou, não muito longe, o ronco da "Doze" de Malaquias, e minha Juriti bateu asas, voando para longe (SUASSUNA, 2014, p. 127).

Findo o primeiro dia, foi Malaquias que colheu os louros como maior caçador.

A segunda caçada se iniciou no dia posterior, com a promessa de caça de jacus e com a disposição dos Pereira em vencer os Quadernas. Notando isso, Dinis emprega de astúcia na defesa não tão somente da honra de sua família, mas a dele próprio, assim assume a frente da organização da caçada e toma lugar de tocaia perto do irmão a fim de, caso necessário, reclamar para a

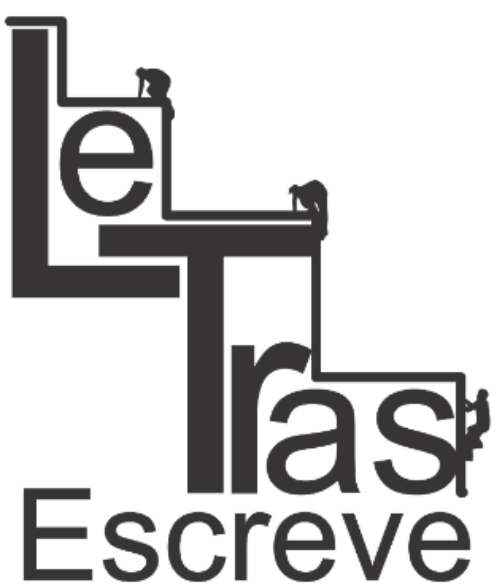

(ISSN 2238-8060) família os feitos do irmão, ou seja, "ganhar no pacote". Na jornada do herói, esse é o momento no qual Quaderna começa a abandonar seu momento de flagelação.

Dinis, novamente, erra "tiro sobre tiro", cabendo a Malaquias a função predatória, derrubando de saída quatro jacus. Dinis, já amedrontado pela humilhação de não ter conseguido nenhuma caça, é abençoado pela Fortuna, que Ihe envia um jacu em sua direção. Acontece que Malaquias atira primeiro na presa, ferindo-a e se aproveitando, segundo o próprio Quaderna, de suas orações mais íntimas. Não se fazendo de rogado, Dinis dá novo tiro no jacu, dessa vez o abatendo. Malaquias correu para buscar o que considerava ser sua presa, mas Quaderna também o faz e, estando mais perto, a cata primeiro. O melhor caçador reclama sua posse, mas Quaderna, em novo exercício de astúcia, apela aos bons sentimentos do irmão, questionando-lhe se ele queria ver seu irmão mais velho humilhado e desmoralizado diante de estranhos. Malaquias cede e o outro fica com o prêmio do Jacu.

Findo o segundo dia, dois dos três irmãos Pereira tinham abatido um jacu cada, empatados com Quaderna e surrados por Malaquias. 
A terceira caçada prometia presas maiores, veados, e se daria na Serra do Reino, onde se localizavam as pedras. Dinis cruzara o limiar de sua jornada e agora se encontrava na paisagem onírica dos relatos régios de sua família, onde deveria vencer a sucessão de provas que a fortuna lhe prometia.

No caminho, passaram pela Lagoa do Vieira, que diziam ser encantada e onde acreditavam que Dom Sebastião tinha uma mina de ouro. Quaderna, auxiliado pela essência divina da Onça-Malhada, assume seu instinto de animal de presa e dispara com seu cavalo em direção à lagoa, como felino atraído por um facho de luz em busca de seu destino régio. Seguindo os postulados de Campbell (2007, p. 102), nesta fase da jornada

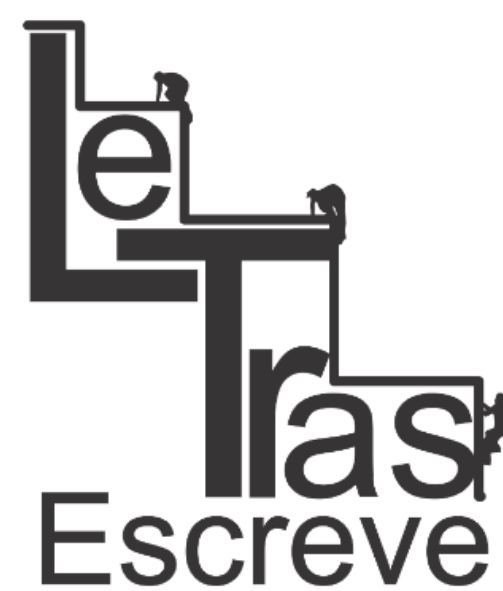

(ISSN 2238-8060)
O herói é auxiliado, de forma encoberta, pelo conselho, pelos amuletos e pelos agentes secretos do auxiliar sobrenatural que havia encontrado antes de penetrar nessa região. Ou, talvez, ele aqui descubra, pela primeira vez, que existe um poder benigno, em toda parte, que o sustenta em sua passagem sobre-humana.

Dinis fingira a seus companheiros que tinha visto caça para justificar sua disparada, e na lagoa, após abater em pleno voo uma Jaçanã, encontra uma pedra com uma marca natural que se assemelhava a um escorpião, além de encontrar o que acreditara ser o forro da coroa que seu bisavô usara na Pedra do Reino:

Era um golpe favorável da Fortuna, e vinha provar, mais uma vez, que a Astrologia não falha. De fato, ainda na "Carnaúba", eu consultara os astros sobre minha expedição, e encontrara o seguinte, no Almanaque: "Para os nascidos sob o signo de Gêmeos, o tempo será favorável, por causa dos influxos benéficos do Planeta Mercúrio. Viagem melhorará assuntos amorosos, financeiros, políticos e sociais. Grande achado. Pessoa mal-intencionada quererá intervir, mas não obterá sucesso. Seja mais observador." Era claro, claríssimo, até! A viagem à Pedra do Reino seria favorável à monarquia dos Quadernas e eu deveria ser o mais observador possível, não só para evitar as interferências daqueles malintencionados Pereiras, como também para entender um sinal, um achado que os astros terminariam me indicando. Ora, no momento, que 


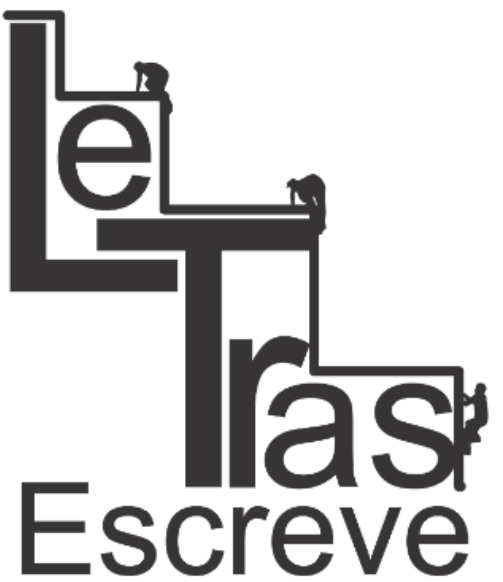

(ISSN 2238-8060) coisa melhor para minha cotação social, política e financeira, do que acertar um tiro daquele?

(...) O mais sensacional, porém, estava ainda por vir. (...) E foi que, no momento em que me curvava para apanhar a pedra, avistei, (...) a Coroa que meu bisavô usara na Pedra do Reino (...), ou antes, sua parte de metal chegara até nós, mas o forro se perdera. Eu já estava, mesmo, conformado em ajustar a ela um chapéu de couro qualquer, que seria digno, mas nunca como o velho forro que servira à cabeça de três Reis. Pode-se imaginar, portanto, qual não foi minha emoção, quando verifiquei que aquele [o forro] tinha umas fendas laterais que coincidiam mais ou menos com as folhas de metal da Coroa! Não havia dúvida, era o forro que, certamente, ficara ali, jogado, no dia da batalha! Era o achado astrológico, predito pelo Almanaque! (SUASSUNA, 2014, p. 138-139).

Quaderna, abençoado pela Fortuna, segue viagem com os demais caçadores em busca da caça de veados. Os princípios de hospitalidade já tinham findado e os Pereiras queriam vencer a todo custo os Quadernas. Deócio, o mais novo dos anfitriões, tomou vanguarda e Dinis nada pôde fazer a não ser se amedrontar "de que fosse um Pereira, e não um Quaderna, o primeiro a matar essa honrosíssima caça que é um Veado" (SUASSUNA, 2014, p. 142), por isso põe-se a rezar a Deus e a seu Planeta que o filho dos Pereiras falhasse, seja não encontrando a presa, seja errando o tiro... Era nova provação ao herói.

Outra vez a Fortuna se faz presente, pois enquanto rezava Quaderna vê uma cobra que dormitava. Num repente, um plano the veio que de uma só "cajadada" derrubaria duas presas: um tiro espantaria qualquer veado que Deócio avistasse e ainda lhe daria mais uma morte. Atirou quase que a queima-roupa na serpente e logrou êxito em manter a honra dos visitantes, além de anexar mais um caractere ao ornato simbólico que compunha sua imagem de caçador.

De então, veado não mais se avistou.

Se o caso do achado do forro da coroa já não fosse suficientemente "bandeiroso", já em cima da serra a Fortuna estende novamente os braços ao herói, com a presa que seria a sagração definitiva da oncidade de Quaderna. Após avistar um pequeno preá,

https://periodicos.unifap.br/index.php/letras

Macapá, v. 6, n. I, Io semestre, 2016. 
Dinis se prepara para abatê-lo. Ele estranha por que o bichinho ficara imobilizado, com um jeito estranho e tenso. Antes do tiro, ponderara se deveria fazê-lo, pois se acertasse fariam-lhe troça com a presa, então decide que, se errasse, diria que era presa maior, caso acertasse, aumentaria em sue relato a distância do tiro. Atira e erra.

Mas...

Com um desgosto danado, sentindo o saibo da derrota e da humilhação, baixei a espingarda; e já ia recomeçar a caminhada para alcançar os outros, quando ouvi um batido estranho por trás da moita. Corri para lá e o coração quase me salta pela boca afora! Ali estava, mortalmente atingida por meu tiro, não uma Cobra, uma cascavel qualquer; não um Jacu, bicho de pena; não um Veado, caça assustada que corre da gente; não nenhuma dessas caças medíocres de caçadores rabos-de-cabra: mas uma Onça, uma Onça de verdade! Não era das Pintadas, é fato. Era uma Suçuarana, menor e parda! Ainda assim, era uma Onça, caça com a qual eu nunca me atrevera a sonhar nem mesmo nos momentos mais agudos de ambição guerreira! O Preá, correndo de mim, só a pressentira a três passos dela: por isso ficara naquela posição que tanto me intrigara. $\mathrm{E}$ eu, cumprindo o ditado que diz "Atirei no que vi, matei o que não vi", errara, por sorte, o Preá e pregara chumbo bem na garganta da Onça! (SUASSUNA, 2014, p. 143-144)

Completara-se 0 destino. Quaderna juntara-se definitivamente, mesmo que não pela força ou pela coragem e sim pela astúcia e pela Sorte, aqueles que tiveram coragem e perícia de matar uma onça. É o momento de "encontro com a deusa", definida por Campbell (2007, p. 111) como "a aventura última, quando todas as barreiras e ogros foram vencidos, [que] costuma ser representada como um casamento místico da alma do herói triunfante com a Rainha-Deusa do Mundo".

$\mathrm{Na}$ cosmogonia cariri da Pedra do Reino, os homens fazem parte da Onça do Mundo, da Onça-Parda da qual são "raça piolhosa". A Onça do Mundo pertence a outra Fera, a Divindade, Onça-Malhada e a morte, a Morte Caetana, que é moça e é onça... Nesta cosmogonia, Quaderna ao ferir mortalmente a suçuarana, apossa-se do caráter divino da onça, em uma antropofagia 
simbólica, podendo, realmente, ser chamado de Pedro Dinis Ferreira-Quaderna, por ter se juntado ao sangue de sua família, àqueles "que, por terem tido a coragem de matar Deus, tinham propiciado a todos os homens a possibilidade ascender e se igualar ao Divino". Quaderna tornara-se o predador maior.

A visagem da morte estava encarnada em animal: "se sou humano, então, neste momento, a onça é somente uma onça. Se uma onça é um humano, neste caso, então, eu não seria mais humano" (CASTRO, 2008, p. 110). Quaderna era agora a onça e a potencialidade deixara de ser uma possibilidade para, finalmente, ser-Ihe uma característica.

[a espingarda] Era, para mim, não tanto uma arma, mas um dos elementos através dos quais eu tentava preservar para mim, para Tia Filipa e para o Povo sertanejo, a imagem cavaleira que me forjara. Eu podia ser, apenas, um Poeta covarde, um Decifrador pacífico de charadas, um exseminarista e Escrivão de gabinete. Mas, graças a meu cavalo de nome heroico, a meu rifle e à minha gloriosa espingarda "Vinte e Oito", podia reivindicar o título de Cavaleiro, soldado e caçador. Se desempenhava bem ou mal essas tarefas, isso era outra história! (SUASSUNA, 2014, p. 123)

Quaderna agora era onça, podia não ser uma pintada, mas desempenhava muito bem o papel de gato-pardo. Poderia não ser o cavaleiro de espadas que o romance europeu perpetuara, mas era o cavaleiro do sertão, o senhor do reino do Cariri, o exilado que derrotara aqueles que lhe negaram o direito de herança.

\section{Referências bibliográficas}

ARENDT, H. Origens do Totalitarismo. Trad. Roberto Raposo. São Paulo: Companhia das Letras, 1990

CAMPBELL, Joseph. O Herói de Mil Faces. São Paulo, SP: Cultrix/Pensamento, 2007

DIDIER, Maria Thereza. Emblemas da consagração Armorial. Recife: UFPE, 2000. 


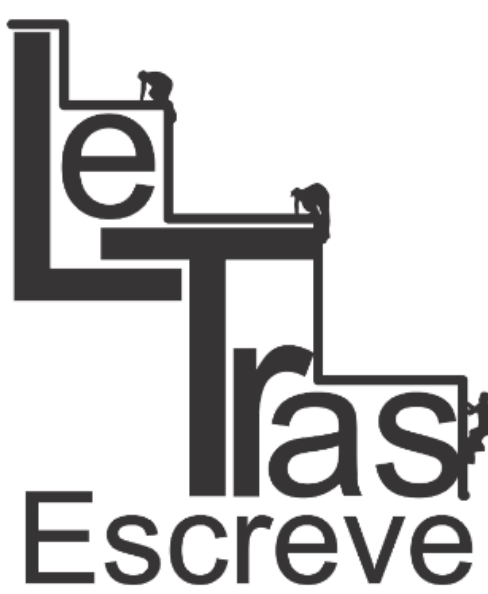

(ISSN 2238-8060)
ECO, Umberto. Confissões de um jovem romancista. Trad. Marcelo Pen. São Paulo: Cosac Naify, 2013.

HUIZINGA, Johan. O outono da Idade Média. Trad. Francis Petra Janssen. São Paulo: Cosac Naify, 2013.

PEREIRA, Marcos Paulo T. A cristalização do imaginário medieval na literatura de cordel. In.: Nau Literária (UFRGS), v. 10, p. 188-207, 2014.

SANTOS, Idelette Muzart Fonseca dos. Em demanda da poética popular: Ariano Suassuna e o Movimento Armorial. $2^{\mathrm{a}}$ ed. Campinas: Editorada Unicamp, 2009.

SANTOS, Milton. A Natureza do Espaço: Tempo, Razão e Emoção. 4a. ed. São Paulo: Editora da Universidade de São Paulo, 2006. SPERBER, Suzi Frankl. Fiç̧ão e Razão: uma retomada das formas simples. São Paulo: Aderaldo \& Rothschild: Fapesp, 2009.

SUASSUNA, Ariano. Romance d'A Pedra do Reino e o príncipe do sangue do vai-e-volta. $14 .^{\text {a }}$ ed. Rio de Janeiro: José Olympio Editora, 2014.

- História d'O Rei Degolado nas Caatingas do Sertão: romance armorial e novela romançal brasileira - Ao sol da Onça Caetana. Rio de Janeiro: José Olympio Editora, 1977.

VIVEIROS DE CASTRO, Eduardo. Encontros. Renato Sztutman (org.). São Paulo: Beco do Azougue Editorial, 2008.

Recebido em 04/06/2016. Aprovado em 27/07/2016. 